\title{
METHOD DEVELOPMENT AND VALIDATION FOR THE ESTIMATION OF AMPRENAVIR IN HUMAN PLASMA BY LIQUID CHROMATOGRAPHY-ELECTROSPRAY IONIZATION-TANDEM MASS SPECTROMETRY
}

\author{
SUSMITHA K ${ }^{1 *}$, MENAKA $\mathbf{M}^{2}$ \\ ${ }^{1}$ Department of Pharmaceutical Chemistry, Annamalai University, Chidambaram, Tamil Nadu, India. ${ }^{2}$ Department of Pharmacy, Annamalai \\ University, Chidambaram, Tamil Nadu, India. Email: susmitha.kondam@gmail.com
}

Received: 11 June 2019, Revised and Accepted: 15 July 2019

ABSTRACT

Objective: The main aim of the present study was to develop a sensitive liquid chromatography-electrospray ionization-tandem mass spectrometric technique for the quantitation of amprenavir in human plasma.

Methods: Chromatographic separation was achieved on a reversed-phase Symmetry $\mathrm{C}_{18}(50 \mathrm{~mm} \times 4.6 \mathrm{~mm}, 3.5 \mu \mathrm{m})$ column with isocratic elution by acetonitrile and $0.1 \% \mathrm{v} / \mathrm{v}$ formic acid in the ratio of $90: 10 \mathrm{v} / \mathrm{v}$ as mobile phase. Chromatographic peaks were resolved with $0.7 \mathrm{ml} / \mathrm{min}$ flow rate. Drug was extracted with ethyl acetate solvent by liquid-liquid extraction method. Monitoring of transition of m/z 506.2 and 71.0 for amprenavir and 628 and 421 for methyl-indinavir was made on multiple reaction monitoring.

Results: Calibration curve of amprenavir was linear over 1-600 ng/ml concentration range with regression coefficient $\left(\mathrm{r}^{2}\right)$ value of $>0.99$. The $\%$ relative standard deviation values were $<8.5 \%$ for interday and intraday precision and accuracy. The method has excellent recovery, and the percentage recovery values of lower quality control (QC), median QC, and higher QC samples were $101.86 \%, 102.8 \%$, and $99.28 \%$, respectively.

Conclusion: The drug was stable for more time at variable stability conditions, and method was successfully applicable to regular analysis of amprenavir in biological matrices.

Keywords: Amprenavir, Protease inhibitor, Liquid chromatography tandem-mass spectrometry, Food and Drug Administration guidelines and dilution integrity.

(C) 2019 The Authors. Published by Innovare Academic Sciences Pvt Ltd. This is an open access article under the CC BY license (http://creativecommons. org/licenses/by/4. 0/) DOI: http://dx.doi.org/10.22159/ajpcr.2019.v12i9.34533

\section{INTRODUCTION}

Amprenavir is a protease inhibitor with activity against human immunodeficiency virus type-1 (HIV-1). Protease inhibitors block the part of HIV called protease. HIV-1 protease is an enzyme required for the proteolytic cleavage of the viral polyprotein precursors into the individual functional proteins found in infectious HIV-1. Amprenavir chemically designated as (3S)-oxolan-3-yl N-[(2S,3R)-3-hydroxy-4-[N(2-methylpropyl)(4-aminobenzene)sulfonamido]-1-phenylbutan-2-yl] carbamate with molecular formula $\mathrm{C}_{25} \mathrm{H}_{35} \mathrm{~N}_{3} \mathrm{O}_{6} \mathrm{~S}$ (Fig. 1) and molecular weight $505.628 \mathrm{~g} / \mathrm{mol}$ [1-3]. Amprenavir binds to the protease active site and inhibits the activity of the enzyme. This inhibition prevents cleavage of the viral polyproteins resulting in the formation of immature non-infectious viral particles. Protease inhibitors are almost always used in combination with at least two other anti-HIV drugs. Amprenavir inhibits the HIV viral proteinase enzyme which prevents cleavage of the gag-pol polyprotein, resulting in noninfectious, immature viral particles. Hepatic amprenavir is metabolized in the liver by the cytochrome P450 3A4 (CYP3A4) enzyme system. The two major metabolites result from oxidation of the tetrahydrofuran and aniline moieties. Glucuronide conjugates of oxidized metabolites have been identified as minor metabolites in urine and feces $[4,5]$.

Drug literature review discloses only few analytical quantification methods for the amprenavir in bulk, formulations, and biological matrices. The reported analytical techniques were high-performance liquid chromatography (HPLC) [6], spectroscopic [7], and liquid chromatography tandem-mass spectrometry (LC-MS/MS) [8]. Goal of the research was to develop a fast and sensitive LC-MS/MS technique for the quantification of amprenavir in human plasma samples and application of method validation as per the regulatory guidelines.

\section{METHODS}

\section{Chemicals and reagents}

Amprenavir (purity: 99.87\%) was obtained from MSN Laboratories, India. Internal standard (IS) (methyl-indinavir) of $99.81 \%$ was acquired from hetero drugs Pvt. Ltd., Hyderabad, India. Acetonitrile of HPLC grade and formic acid of analytical grade were bought from J.T.Baker, Hyderabad, India. In the present research work, water used from Milli-Q water purification system installed in the laboratory obtained from Bengaluru, India.

\section{LC-MS/MS system}

A modular LC system (Shimadzu, Japan) equipped with a DGU20A3 solvent degasser, binary LC-20AD prominence pump, column temperature ovens (CTO)-ASVP-oven for column, and high-throughput SILHTC autosampler were utilized for the present research.

Chromatography was achieved on a reversed-phase (RP) Symmetry $\mathrm{C}_{18}(50 \mathrm{~mm} \times 4.6 \mathrm{~mm}, 3.5 \mu \mathrm{m})$ with isocratic elution by acetonitrile and $0.1 \% \mathrm{v} / \mathrm{v}$ formic acid in the ratio of $90: 10 \mathrm{v} / \mathrm{v}$ as mobile phase. Chromatographic peaks were resolved by the mobile phase with a flow rate of $0.7 \mathrm{ml} / \mathrm{min}$. Amprenavir and methyl-indinavir internal standard were separated in the total run time of $5 \mathrm{~min}$. The autosampler temperature and analytical column temperatures were kept at $5^{\circ} \mathrm{C}$ and $35^{\circ} \mathrm{C}$, respectively.

The eluents of the LC system were infused into the electrospray ionization source operated with positive ionization method. Starting 0.5 min eluent was avoided from the chromatographic system to evade unnecessary impurities from the various salts existed in the human plasma samples. 
In the mass system, following conditions were applied: Gas-1 - nitrogen (40 psi), gas-2 - nitrogen (40 psi), temperature of ion source $-400^{\circ} \mathrm{C}$, curtain gas - nitrogen (25 psi), and voltage of ion spray - $5000 \mathrm{~V}$. Monitoring of transition of $\mathrm{m} / \mathrm{z} 506.2$ and 71.0 for amprenavir and 628 and 421 for methyl-indinavir was made on multiple reaction monitoring. The mass conditions are presented in Table 1.

\section{Sample preparation}

To $250 \mu \mathrm{l}$ of spiked plasma, $50 \mu \mathrm{l}$ of methyl-indinavir $(1 \mu \mathrm{g} / \mathrm{ml})$ was mixed and sonicated for $15 \mathrm{~s}$. To the resulting solution, $500 \mu \mathrm{l}$ of ethyl acetate was added and vortexed for $5 \mathrm{~min}$, followed by centrifuged at $5000 \mathrm{rpm}$ for $10-20 \mathrm{~min}$ at $5^{\circ} \mathrm{C}$. The organic phase was dried in a lyophilizer. The final residue was dissolved in $200 \mu \mathrm{l}$ of mobile phase and transferred into a pre-labeled autosampler vials and infused into an LC-MS/MS system.

\section{Preparation of standard stock and calibration standards (CCs)}

Amprenavir and IS stock solutions were processed in $60 \%$ methanol at concentration level of $1000 \mu \mathrm{g} / \mathrm{ml}$. Quality control (QC) and CC solutions were processed by spiking blank human plasma sample from the amprenavir stock solution. CC solutions of eight concentration levels were prepared to produce the final concentrations of 2.0, $4.0,20.0,40.0,100.0,200.0,300.0$, and $600.0 \mathrm{ng} / \mathrm{ml}$. Lower QC (LQC) standard, median QC (MQC) standard, and higher QC (HQC) standards were QC sample solutions and were prepared to produce the concentrations of 4,200 , and $500 \mathrm{ng} / \mathrm{ml}$, respectively. All the stock, CC and QC solutions were stored at $-20^{\circ} \mathrm{C}$ till the method of analysis.

\section{Validation}

The method of analysis was assessed by validation parameters such as sensitivity, precision, linearity, recovery, dilution integrity, accuracy, matrix effect (ME), and stability. Three QC samples of LQC, MQC, and HQCs as well as lower limit of quantification (LLOQ) were employed and analyzed in method validation [9-12].

\section{Precision and accuracy (PA)}

Intraday and interday PA were examined as a part of PA parameter. Intraday PA was evaluated by injecting QC solutions $(2,200$, and $500 \mathrm{ng} / \mathrm{ml})$ and LLOQ $(1.0 \mathrm{ng} / \mathrm{ml})$ in 5 replicates in a day arbitrarily. Interday PA was evaluated by injecting the same QC and LLOQ solutions once in a day for 5 different days. The $\%$ relative standard deviations (RSDs) for LQC, MQC, and HQCs should be $\leq 20 \%$ for LLOQ and $\leq 15 \%$ for the remaining QC standards [13].

\section{Linearity}

CC standards (non-zero) of 8 different concentrations at 2.0, 4.0, $20.0,40.0,100.0,200.0,300.0$, and $600.0 \mathrm{ng} / \mathrm{ml}$ were prepared and analyzed in three separate runs. Linearity curve (peak area ratio of amprenavir and methyl-indinavir peaks against nominal concentration) was plotted by least squares linear regression and reciprocal of the squared concentration $\left(1 / x^{2}\right)$ used as a weighting factor. Deviation should be within $\pm 20 \%$ for LLOQ and $\pm 15 \%$ for remaining concentrations.

\section{Specificity and selectivity}

Method selectivity was analyzed by comparing the chromatograms obtained from blank and spiked solutions. Method specificity was analyzed by infusing six different lots of blank plasma solutions to ensure no endogenous compounds interfere with amprenavir and IS.

\section{Recovery and ME}

Amprenavir recovery was evaluated by paralleling the mean peak areas of extracted and un-extracted samples at low, medium, and high QC standard levels. At each concentration level, percentage recoveries were calculated, and finally, overall mean recovery was calculated. The ME was analyzed by paralleling the un-extracted samples with post-extracted samples [14-16].

$$
\begin{aligned}
& \text { Mean amprenavir peak response } \\
& \% \text { Recovery of amprenavir }=\frac{\text { in extracted samples }}{\text { Mean amprenavir peak response }} \times 100 \\
& \text { in un - extracted samples }
\end{aligned}
$$

\section{Stability}

Stability was analyzed at LQC, MQC, and HQC levels. It includes benchtop, freeze-thaw, autosampler, and long-term stabilities. The bench-top stability was evaluated for $5 \mathrm{~h}$ at ambient temperature $\left(25^{\circ} \mathrm{C}\right)$. Freeze and thaw stability was analyzed by storing the $\mathrm{QC}$ samples at $-70^{\circ} \mathrm{C}$ for at least $3 \mathrm{~h}$, and for thaw cycle, keep the solutions at room temperature. Repeat the freeze and thaw cycles for 3 times. The autosampler stability was analyzed by placing the QC solutions in autosampler at $10^{\circ} \mathrm{C}$ for $8 \mathrm{~h}$. Long-term stability was evaluated by placing the QC samples in a freezer at $-70^{\circ} \mathrm{C}$ for 3 months [17-19].

\section{Dilution integrity}

The sample solution above the upper limit of calibration range was prepared and evaluated for PA parameters. The percentage nominal concentration must be $\pm 15 \%$.

\section{Ruggedness}

Method ruggedness was assessed by processing QC standards for one PA batch utilizing different columns of the same composition by different analysts. The \%RSDs for LQC, MQC, and HQCs should be $\leq 20 \%$ for LLOQ and $\leq 15 \%$ for the remaining QC standards.

\section{RESULTS AND DISCUSSION}

The LC-MS/MS chromatograms of amprenavir - blank and LLOQ and LQC, MQC, and HQC concentration levels - are shown in Figs. 2 and 3.

\section{Method validation}

Specificity

From the Figs. 2 and 3, system chromatographic conditions were clearly separating amprenavir and IS from endogenous and other plasma<smiles>CC(C)CN(C[C@H](O)[C@H](Cc1ccccc1)NC(=O)O[C@H]1CCOC1)S(=O)(=O)c1ccc(N)cc1</smiles>

\begin{tabular}{|c|c|c|c|c|c|c|c|}
\hline Component & Precursor ion $(\mathrm{m} / \mathrm{z})$ & Product ion $(\mathrm{m} / \mathrm{z})$ & $\mathrm{DP}(\mathrm{V})$ & EP (V) & $\operatorname{CEP}(V)$ & CE (V) & $\operatorname{CXP}(\mathrm{V})$ \\
\hline Amprenavir & 506.2 & 71.0 & 40 & 8 & 25 & 30 & 5 \\
\hline Methyl-indinavir & 628 & 421 & 100 & 8 & 25 & 82 & 5 \\
\hline
\end{tabular}

Fig. 1: Structure of amprenavir

Table 1: Mass conditions for amprenavir and IS

DP: Declustering potential, EP: Entrance potential, CEP: Collision cell entrance potential, CE: Collisional energy, CXP: Collision cell exit potential, IS: Internal standard 
substances. The amprenavir-LLOQ peak response is more than $20 \%$ the interference peak response, and methyl-indinavir peak response is more than $5 \%$ from the interference peak response.

PA

Amprenavir interday and intraday PA were analyzed, and the \%RSD values are calculated for the same and are tabulated in Table 2.

Table 2: Amprenavir precision and accuracy data

\begin{tabular}{llllll}
\hline $\begin{array}{l}\text { Nominal } \\
\text { concentration } \\
\text { (ng/ml) }\end{array}$ & Intraday & & \multicolumn{2}{l}{ Interday } \\
\cline { 2 - 3 } \cline { 5 - 6 } & Accuracy (\%) & \%RSD $^{\mathbf{n}}$ & & Accuracy (\%) & \%RSD $^{\mathbf{n}}$ \\
\hline 2 & 104.6 & 4.5 & 107.5 & 5.2 \\
4 & 89.6 & 3.9 & & 91.6 & 6.1 \\
200 & 105.2 & 2.5 & & 101.2 & 4.2 \\
500 & 109.8 & 8.1 & 96.4 & 2.9 \\
\hline
\end{tabular}

$\mathrm{n}=6$ replicates (for precision), RSD: Relative standard deviation
Linearity

Amprenavir calibration graph was linear in the concentration range of $2-600 \mathrm{ng} / \mathrm{ml}$ with regression equation of $\mathrm{Y}=0.4528 \mathrm{X}+3.145$. The regression coefficient $\left(\mathrm{r}^{2}\right)$ value is more than 0.99 which was acceptable as per the Food and Drug Administration (FDA) regulatory guidelines [18].

\section{Recovery and $M E$}

The method has excellent recovery and the percentage recovery values were $101.86 \%, 102.8 \%$, and $99.28 \%$ for LQC, MQC, and HQC samples, respectively. The data for amprenavir recovery are tabulated in Table 3. The ME was evaluated at LQC and HQC level, and the calculated \% coefficient of variation (CV) values was $4.59 \%$ and $3.68 \%$, respectively.

\section{Dilution integrity}

Dilution integrity of amprenavir was performed and evaluated. The percentage nominal was within the limit $( \pm 15 \%)$, and the estimated precision was $\leq 15 \%$. It shows that the drug can be dilute to 20 times and the results will be reproducible.

Table 3: Recovery data for amprenavir

\begin{tabular}{|c|c|c|c|c|c|c|c|c|c|}
\hline \multirow[t]{2}{*}{ ID } & \multicolumn{3}{|l|}{ LQC } & \multicolumn{3}{|l|}{ MQC } & \multicolumn{3}{|l|}{ HQC } \\
\hline & $\begin{array}{l}\text { Un } \\
\text { extracted } \\
\text { (Area ratio) }\end{array}$ & $\begin{array}{l}\text { Extracted } \\
\text { (Area ratio) }\end{array}$ & \%Recovery & $\begin{array}{l}\text { Un } \\
\text { extracted } \\
\text { (Area ratio) }\end{array}$ & $\begin{array}{l}\text { Extracted } \\
\text { (Area ratio) }\end{array}$ & \%Recovery & $\begin{array}{l}\text { Un } \\
\text { extracted } \\
\text { (Area ratio) }\end{array}$ & $\begin{array}{l}\text { Extracted } \\
\text { (Area ratio) }\end{array}$ & \%Recovery \\
\hline 1 & 0.213 & 0.251 & 117.85 & 0.648 & 0.634 & 98.451 & 0.897 & 0.885 & 98.66 \\
\hline 2 & 0.246 & 0.235 & 95.59 & 0.612 & 0.65 & 106.20 & 0.905 & 0.879 & 97.12 \\
\hline 3 & 0.254 & 0.249 & 98.03 & 0.598 & 0.635 & 106.18 & 0.856 & 0.985 & 115.07 \\
\hline 5 & 0.214 & 0.219 & 102.34 & 0.675 & 0.684 & 101.33 & 0.965 & 0.845 & 87.56 \\
\hline 6 & 0.243 & 0.239 & 98.35 & 0.598 & 0.665 & 111.20 & 0.895 & 0.912 & 101.89 \\
\hline Mean & 0.23 & 0.24 & 101.86 & 0.64 & 0.6525 & 102.80 & 0.912 & 0.903 & 99.28 \\
\hline SD & 0.017 & 0.014 & 7.42 & 0.02 & 0.017 & 5.80 & 0.037 & 0.04 & 8.301 \\
\hline$\% \mathrm{CV}$ & 7.29 & 5.83 & 7.28 & 5.68 & 2.62 & 5.64 & 4.11 & 4.77 & 8.36 \\
\hline
\end{tabular}

LQC: Lower quality control, MQC: Median quality control, HQC: Higher quality control

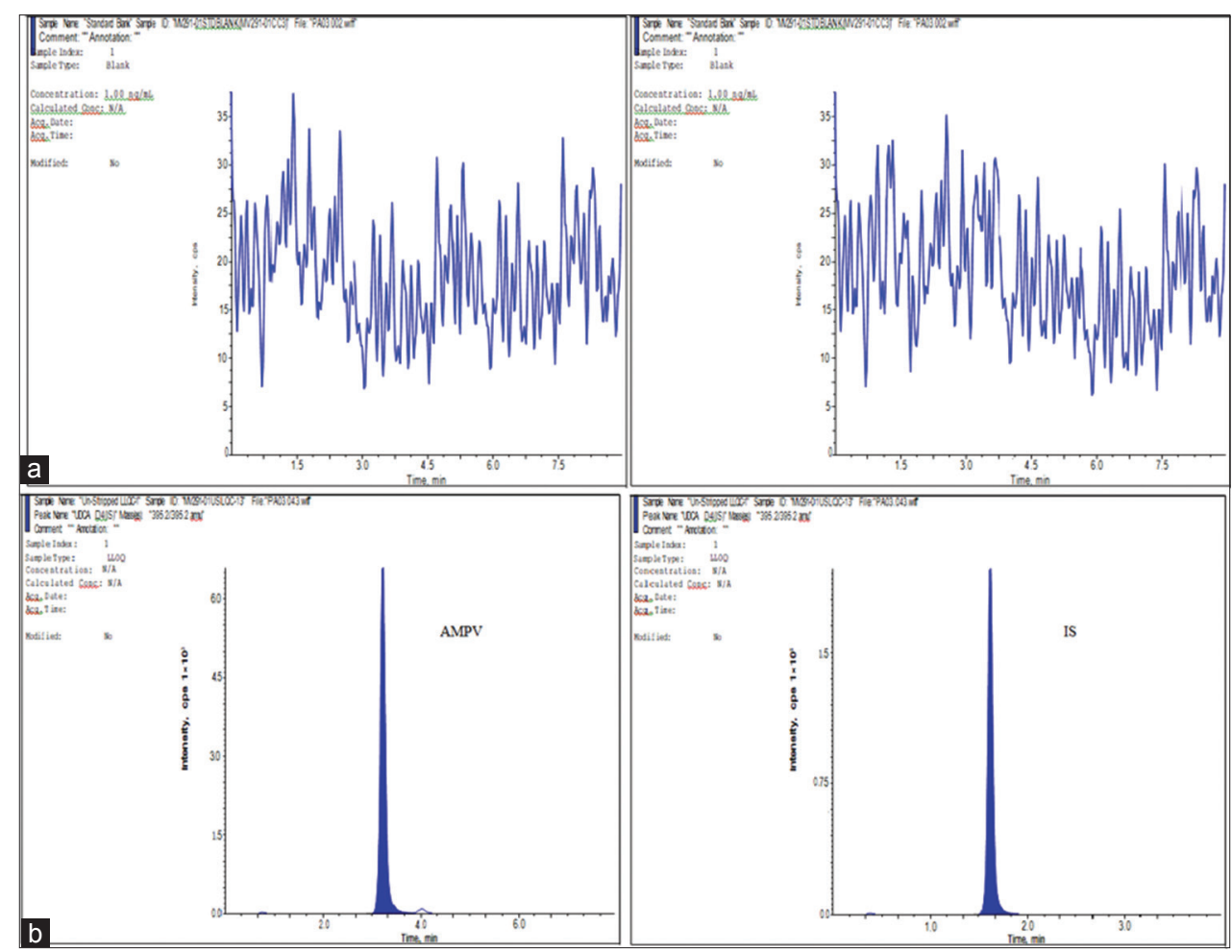

Fig. 2: Amprenavir chromatograms (a) blank and (b) spiked lower limit of quantification samples 


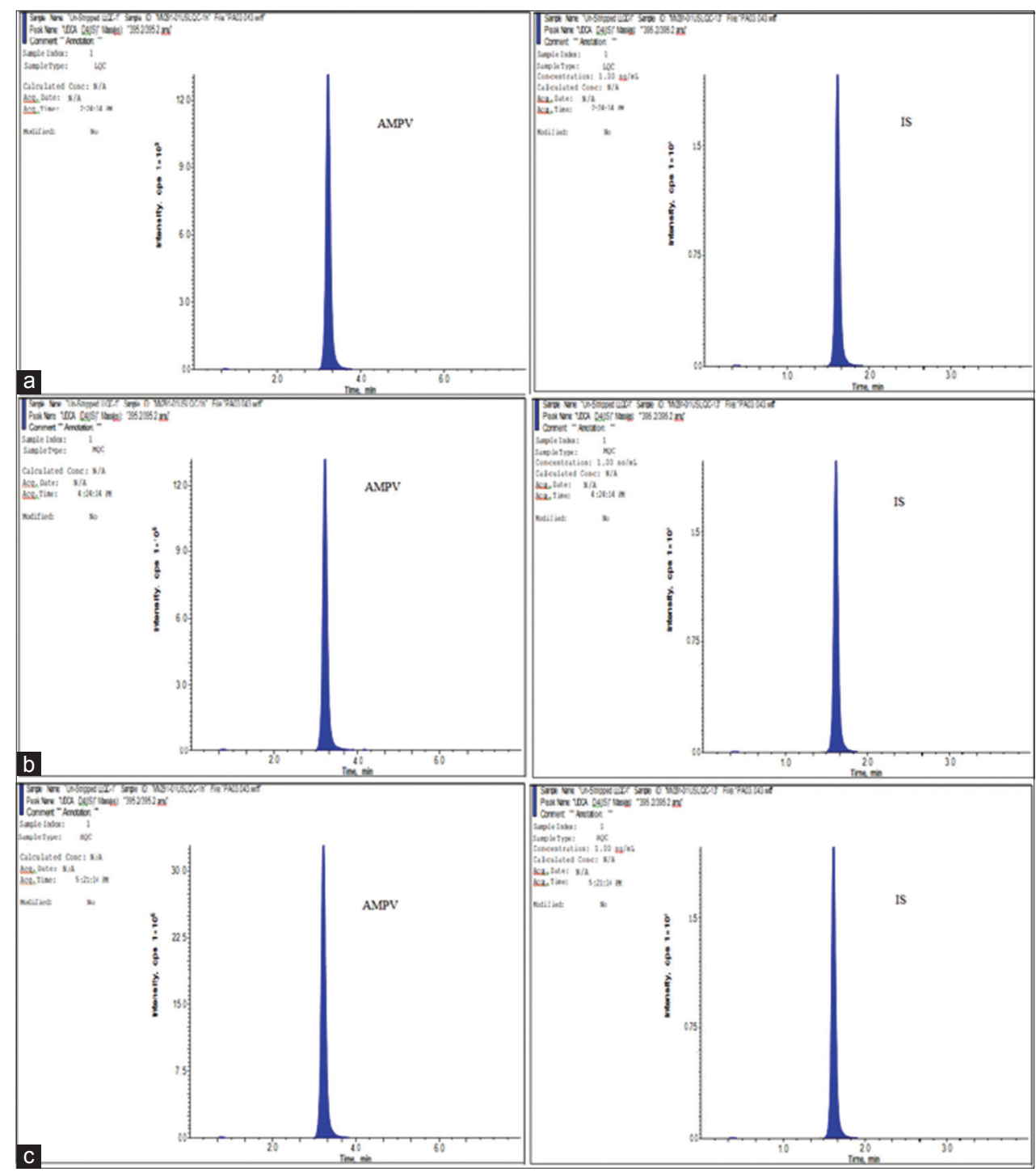

Fig. 3: Chromatograms of amprenavir spiked (a) lower quality control, (b) median quality control, and (c) higher quality control samples

Table 4: Stability for amprenavir

\begin{tabular}{|c|c|c|c|c|c|c|c|c|c|}
\hline \multirow[t]{2}{*}{ Drug } & \multirow[t]{2}{*}{$\begin{array}{l}\text { Concentration } \\
(\mathrm{ng} / \mathrm{ml})\end{array}$} & \multicolumn{2}{|c|}{ Bench-top stability } & \multicolumn{2}{|c|}{$\begin{array}{l}\text { Autosampler } \\
\text { stability }\end{array}$} & \multicolumn{2}{|c|}{$\begin{array}{l}\text { Freeze and thaw } \\
\text { stability }\end{array}$} & \multicolumn{2}{|c|}{ Long-term stability } \\
\hline & & $\begin{array}{l}\text { Mean } \pm S D \\
\text { (ng/ml) }\end{array}$ & $\% \mathrm{CV}$ & $\begin{array}{l}\text { Mean } \pm \text { SD } \\
\text { (ng/ml) }\end{array}$ & $\% \mathrm{CV}$ & $\begin{array}{l}\text { Mean } \pm S D \\
(\mathrm{ng} / \mathrm{ml})\end{array}$ & $\% \mathrm{CV}$ & $\begin{array}{l}\text { Mean } \pm \text { SD } \\
\text { (ng/ml) }\end{array}$ & $\% \mathrm{CV}$ \\
\hline Amprenavir & $\begin{array}{l}4 \\
200 \\
500\end{array}$ & $\begin{array}{l}4 \pm 0.5 \\
200 \pm 17.0 \\
500 \pm 20\end{array}$ & $\begin{array}{l}10.7 \\
9.6 \\
6.6\end{array}$ & $\begin{array}{l}4 \pm 0.3 \\
200 \pm 11.0 \\
500 \pm 8.0\end{array}$ & $\begin{array}{l}6.1 \\
8.6 \\
4.6\end{array}$ & $\begin{array}{l}4 \pm 0.2 \\
200 \pm 8.0 \\
500 \pm 7.3\end{array}$ & $\begin{array}{l}5.3 \\
4.6 \\
9.4\end{array}$ & $\begin{array}{l}4 \pm 0.2 \\
200 \pm 10.0 \\
500 \pm 11.0\end{array}$ & $\begin{array}{l}6.1 \\
5.3 \\
8.3\end{array}$ \\
\hline
\end{tabular}

SD: Standard deviation, CV: Coefficient of variance

\section{Stability}

All the QC standards were exposed to different stability conditions and evaluated to analyze the stability of amprenavir. From evaluated \%CV stability data, the drug was stable for more time at variable conditions such as bench-top stability $(<10.8 \%)$, freeze-thaw stability $(<9.5 \%)$, autosampler stability ( $<8.9 \%)$, and long-term stability $(<8.4 \%)$, and the values are presented in Table 4 .

\section{Ruggedness}

Method ruggedness for amprenavir was performed and evaluated. The $\%$ RSD values are calculated for the same and are tabulated in Table 5.
Table 5: Amprenavir ruggedness data

\begin{tabular}{llllll}
\hline $\begin{array}{l}\text { Nominal } \\
\text { concentration } \\
\text { (ng/ml) }\end{array}$ & $\begin{array}{l}\text { Analyst-1 and } \\
\text { column-1 }\end{array}$ & & \multicolumn{2}{l}{$\begin{array}{l}\text { Analyst-2 and } \\
\text { column-2 }\end{array}$} \\
\cline { 2 - 3 } \cline { 5 - 6 } & $\begin{array}{l}\text { Accuracy } \\
\text { (\%) }\end{array}$ & \%RSD $^{\mathbf{n}}$ & & $\begin{array}{l}\text { Accuracy } \\
\text { (\%) }\end{array}$ & \%RSD $^{\mathbf{n}}$ \\
& 106.3 & 5.2 & & 102.6 & 6.8 \\
\hline 2 & 98.4 & 2.9 & & 94.6 & 5.9 \\
4 & 105.8 & 6.8 & & 97.2 & 3.8 \\
500 & 104.2 & 2.6 & & 106.9 & 4.5 \\
\hline
\end{tabular}

n: 6 replicates, RSD: Relative standard deviation 


\section{CONCLUSION}

A bioanalytical LC-MS/MS method for the amprenavir was developed and validated with methyl-indinavir as IS. This method has excellent recovery, accuracy, and precision compared with existed methods for the analysis of drug in human plasma samples. The drug was extracted from plasma samples by liquid-liquid extraction method with ethyl acetate as an extraction solvent. The drug was eluted within 5 min using RP Symmetry $\mathrm{C}_{18}(50 \mathrm{~mm} \times 4.6 \mathrm{~mm}, 3.5 \mu \mathrm{m})$ column with isocratic elution by acetonitrile and $0.1 \% \mathrm{v} / \mathrm{v}$ formic acid in the ratio of $90: 10 \mathrm{v} / \mathrm{v}$ as mobile phase. The developed technique was validated according to the FDA regulatory guidelines, and all the validation parameters were within the acceptable range. The developed technique was effectively applied to routine analysis of amprenavir in plasma samples.

\section{AUTHORS' CONTRIBUTIONS}

All authors contribute equally to this manuscript.

\section{CONFLICTS OF INTERESTS}

The authors declare that there are no conflicts of interests regarding the publication of this paper.

\section{REFERENCES}

1. Shen CH, Wang YF, Kovalevsky AY, Harrison RW, Weber IT. Amprenavir complexes with HIV-1 protease and its drug-resistant mutants altering hydrophobic clusters. FEBS J 2010;277:3699-714.

2. Wittayanarakul K, Hannongbua S, Feig M. Accurate prediction of protonation state as a prerequisite for reliable MM-PB(GB)SA binding free energy calculations of HIV-1 protease inhibitors. J Comput Chem 2008;29:673-85

3. Dandache S, Sévigny G, Yelle J, Stranix BR, Parkin N, Schapiro JM, et al. In vitro antiviral activity and cross-resistance profile of PL-100, a novel protease inhibitor of human immunodeficiency virus Type 1. Antimicrob Agents Chemother 2007;51:4036-43.

4. Sadler BM, Hanson CD, Chittick GE, Symonds WT, Roskell NS. Safety and pharmacokinetics of amprenavir (141W94), a human immunodeficiency virus (HIV) Type 1 protease inhibitor, following oral administration of single doses to HIV-infected adults. Antimicrob Agents Chemother 1999;43:1686-92.

5. Agenerase (amprenavir) Capsules. Full Prescribing Information. Section Dosage and Administration. US Food and Drug Administration. GlaxoSmithKline and Vertex Pharmaceuticals Inc. Available from: . [Last retrieved on 2015 Nov 29].
6. Rajitha K, Prasanna NL, Naveen R, Ranjith CH, Kumar AA. A rapid RP-HPLC method development and validation for the quantitative estimation of indinavir in capsules. Int J Pharm Pharm Sci 2014;6:453-6.

7. Padmini T, Satyanarayana L. Spectrophotometric determination of amprenavir by complex formation in bulk drug and formulation samples. Int J Pharm Clin Res 2017;9:521-4.

8. Chi J, Jayewardene AL, Stone JA, Motoya T, Aweeka FT. Simultaneous determination of five HIV protease inhibitors nelfinavir, indinavir, ritonavir, saquinavir and amprenavir in human plasma by LC/MS/MS. J Pharm Biomed Anal 2002;30:675-84.

9. Koehn J, Ding Y, Freeling J, Duan J, Ho RJ. A simple, efficient, and sensitive method for simultaneous detection of anti-HIV drugs atazanavir, ritonavir, and tenofovir by use of liquid chromatographytandem mass spectrometry. Antimicrob Agents Chemother 2015;59:6682-8

10. Das Mishra T, Kurani H, Singhal P, Shrivastav PS. Simultaneous quantitation of HIV-protease inhibitors ritonavir, lopinavir and indinavir in human plasma by UPLC-ESI-MS-MS. J Chromatogr Sci 2012;50:625-35.

11. US FDA. Guidance for Industry Bioanalytical Method Validation, Food and Drug Administration, Center for Drug Evaluation and Research (CDER). Rockville, Maryland: USA; 2001

12. Tijare LK, Rangari NT, Mahajan UN. A review on bioanalytical method development and validation. Asian J Pharm Clin Res 2016;9:6-10.

13. Liliya L, Dmytro K, Oleksandra O, Taras P, Mariya D. A HPLCMS/MS method development and validation for the simultaneous determination of bisoprolol and enalapril in the present of enalaprilat in human plasma. Int J Appl Pharm 2018;10:31-40.

14. Swathi P, Vidyadhara S, Sasidhar RL, Chakravarthi KK. Method development and validation for the estimation of entecavir in bulk and pharmaceutical dosage forms by RP-HPLC. Int J Curr Pharm Res 2017;9:107-11.

15. Ravi Y, Rajkamal B. An improved LC-MS/MS method development and validation for the determination of trandolapril and verapamil in human plasma. Int J Pharm Pharm Sci 2018;11:91-5.

16. ICH: Q2B. Harmonized Tripartite Guideline, Validation of Analytical Procedure: Methodology, IFPMA. Geneva: Proceedings of the International Conference on Harmonization; 1996.

17. ICH: Q2 (R1). Validation of Analytical Procedures: Text and Methodology. International Conference on Harmonisation; 2005.

18. Lakshmi PR, Prahlad P, Ravindra N, Rao MV. A rapid and sensitive liquid chromatography mass spectrometry/mass spectrometry method for estimation of pioglitazone, keto pioglitazone and hydroxy pioglitazone in human plasma. Asian J Pharm Clin Res 2017;10:120-8.

19. Hepsebah NJ, Kumar AA. Bioanalytical method development and validation of ibrutinib in biological matrices by LC-MS/MS. Int J Pharm Pharm Sci 2018;11:22-6. 